IP Periodica Polytechnica

Social and Management

Sciences

24(2), pp. 83-87, 2016

DOI: $10.3311 /$ PPso. 8765

Creative Commons Attribution (i)

RESEARCH ARTICLE

\section{Prediction of Manipulation, Empathy and Social Irritability through Selected Personality Traits among Managers}

\author{
Tatiana Lorincová ${ }^{1 *}$, Anna Lelková ${ }^{1}$
}

Received 05 November 2015; accepted 02 February 2016

\begin{abstract}
The contribution analyzes manipulation, empathy and social irritability through verification of predictive power personality traits (sociability, emotional stability and self-confidence). The research sample is based on head officers and managers in Bratislava and Presov County, working in both private and public organisations. The aim of the study is to analyze predictive power of selected personality traits to manipulation, empathy and social irritability. The research data were collected through BIP questionnaire (Bochum Personality Questionnaire) in slovak translation by Džuka (2002) and MESI questionnaire (Manipulation, Empathy and Social irritability) by Frankovský and Birknerová (2014). Base on the confirmed aspects we came to the conclusion that sociability and selfconfidence have significant predictive power in predicting manipulation. Sociability and emotional stability do not have significant power in predicting empathy. Sociability has significant predictive power in predicting social irritability but on the other hand self-confidence does not have significant predictive power in predicting social irritability.
\end{abstract}

\section{Keywords}

manipulation, empathy, social irritability, personality traits, managers

\section{Introduction}

The recent studies define personality and personality traits in different ways. Personality is a multidimensional construct and according to Mayer (1998), a personality should be perceived as a system which is defined by the adequate theories. The theories differentiate between individual elements, describe their organization, mutual connection and development. McAdams (1996) suggests 3 stages of personality system: personal features, strategies of managing, skills, values and life stories. McCrae and Costa (1987) applied the stages to create „The Five-Factor Personality System“. The structure of our personality affects the individual personality parts. The analysis of individual characteristics clarify the actual characteristics and dispositions.

Personal characteristics - Five-Factor model includes the general principles of features theories, according to which an individual can be characterized on the relatively permanent basis of thinking, feeling and activities. Smekal (2002) lists those personal characteristics that best differentiate people: neuroticism, extraversion, openness, agreeableness and conscientiousness. These personal characteristics include selected personality traits as sociability, empathy and self-confidence.

\subsection{Manipulation}

In this paragraph we define manipulation and manipulative behaviour. Oravcová (2004) argues that manipulation is one of the behaviour ways between people and defines it as an asymmetric interaction, where one side uses the other side to reach their own goals. It is a way of influencing other people, where their actions are the means of the manipulator to gain what they need.

Manipulative behaviour characteristics:

- motivated by personal success of manipulator

- the goals are hidden and behaviour is camouflaged

- taking advantage of other persons for own benefits of manipulator

Spurny (1996) says that manipulation is a way of communication, where we act and change our opinion under the

\footnotetext{
${ }^{1}$ Department of Managerial Psychology, Faculty of Management,

University of Prešov in Prešov, Konštantínova 16, 08001 Prešov, Slovakia

*Corresponding author, e-mail: tatiana.lorincova@unipo.sk
} 
emotional arguments pressure, we adapt to manipulators goals. The author also defines other types of manipulative behaviour:

- authoritative statements, referencing to the authority

- "feel-sorry" strategy

- picks on the mistakes of others, but reminds everyone his credits

- arrogant and vile manipulation

- whether you like it or not, he knows what's the best for you

Edmüller and Wilhelm (2003) say, the manipulation is conscious and unconscious use of unfair procedures and behaviour. The manipulation can occur in all types of communication, for example, the informational interview, consultation, management meeting, friendly or critical conversation and so on.

\subsection{Empathy}

Empathy is treated as a moral virtue at both the organizational and individual levels. First, at the organizational level empathy is a basis of compassion and connectedness (e.g., Dutton et al., 2006; Pavlovich and Krahnke, 2012). Second, at the individual level it is a human quality of moral goodness (Park and Peterson, 2008). Cawley et al. (2000), for example, examined empathy as a component in their virtues approach to personality. These scientists found that empathy was consistently related to extraversion and agreeableness and concluded that it was, at least in part, based on personality. The fundamental position of the "empathy as a virtue" approach is that empathy motivates human behaviour that creates positive consequences for other people and stakeholders.

\subsection{Social irritability}

Social irritability is connected to emotional regulation and it is possible to say, that social irritability is a disability to regulate own emotion. Emotion regulation, defined as efforts to influence which emotions we have, when we have them, and how these emotions are experienced or expressed (Gross, 1998) can benefit individuals in their day-to-day work lives (Lawrence et al., 2011).

A core feature is that it includes a person's efforts to intensify, suppress or maintain both positive and negative emotions and this takes place along a continuum of conscious effort through to automatic regulation (Gross and Thompson, 2007).

For example, Niven et al. (2013) found that emotion regulation moderated the effects of workplace aggression on employee strain. Emotion regulation has been explored in interpersonal relations (e.g., as a demand for emotional labour). Definitions mentioned above form the basis for empirical part of this paper.

\section{Methodology}

The main goal of the research is to analyze manipulation, empathy and social irritability through verification of predictive power in selected personality traits (sociability, emotional stability and self-confidence).

Hypothesis 1: We assume that sociability and self-confidence contribute to prediction of manipulation in significant level. Hypothesis 2: We assumed that sociability and emotional stability contribute to prediction of empathy in significant level. Hypothesis 3: We assumed that sociability and self-confidence contribute to prediction of social irritability in significant level.

\section{Research sample}

Research sample consisted of 111 participants aged from 23 to 57 years (average age was 33.92 with standard deviation of 7.894). The proportionality of genders was uneven- the sample contained 35 women and 76 men. The research sample consisted of head officers and managers in Bratislava and Presov County, working in both private and public organisations. Table 1 illustrates descriptive data of research variables.

Table 1 Descriptive statistics of variables

\begin{tabular}{llll}
\hline MESI & Mean & Std. Deviation & $\mathrm{N}$ \\
\hline Manipulation & 1.622 & 0.550 & 111 \\
Empathy & 2.322 & 0.459 & 111 \\
Social irritability & 1.552 & 0.648 & 111 \\
BIP & $\mathrm{x}$ & $\mathrm{x}$ & $\mathrm{x}$ \\
Emotional stability & 2.303 & 0.486 & 111 \\
Sociability & 2.821 & 0.503 & 111 \\
Self-confidence & 2.343 & 0.539 & 111 \\
\hline
\end{tabular}

\section{Research methods}

\subsection{Bochum Personality Questionnaire- BIP}

We used 3 dimensions of BIP Questionnaire to collect the data of Emotional Intelligence- Bochum Inventory of professional personality characteristics, developed by two german authors, Rüdiger Hossiep a Michael Paschen (2003), translated by Jozef Džuka (2002). The BIP Questionnaire contains 210 statements about human's behaviour and habits. The statements are related to the professional life. The individual entries are rated on the scale 1-6 (ranging from ,perfectly suitable“ to „,non suitable at all“).

The questionnaire scale reflects practice requirements of personal characteristics. BIP Questionnaire is divided into 4 global parts, which form 14 dimensions of professional behaviour where every dimension is represented by different amount of elements. We used 3 factors for the research purposes with the Cronbach Alfa $=0.784$.

The first factor was sociability, from the field of Social competencies, stated by 15 items. Emotional stability consists of 16 items and Self-confidence consists of 16 items from the field of Mental constitution. 


\subsection{MESI- Manipulation, Empathy and Social irritability}

The MESI methodology is inspired by PESI methodology, which was developed by Kaukiainen, Björkqvist, Osterman, Lagerspetz, a Forsblom (1995). The original methodology was created for children of same age or their teachers to identify the level of perception of social intelligence. It contains 10 items within its internal consistency (Cronbach alpha) is 0.90 . The methodology MESI contains 21 items, which are considered in 5 - points scale $(0$ - never, 4 - very often). By factor analysis were extracted three main factors - empathy, manipulation and social irritability. Frankovský and Birknerová (2012) extracted 3 factors of social intelligence:

Empathy: The individual with higher scores know how to identify intentions, feelings and weakness of the others. They can adapt to new people and fulfil their expectations.

Manipulation: The individuals with higher scores in this factor are able to convince others to do what they need. They know how to use them and convert them to stand on their side. They do not hesitate to use lies as a resource for their own benefit.

Social irritability: Persons with higher score in this factor are annoyed by communication with other people, not able to adapt, can't stand weakness.

These factors by number and content correspond with results of MESI methodology on Slovak research sample (Birknerová and Frankovský, 2014). Extracted factors show $47.7 \%$ variance, which is acceptable and allowed to specify factors by content. Internal consistency of individual factors was determined by Cronbach coefficient and the values are acceptable.

\section{Research results}

The objective of research is to analyze manipulation, empathy and social irritability through verification of predictive power in selected personality traits (sociability, emotional stability and self-confidence). The results were processed in statistic program SPSS 17 and assessed by regression analysis. Table 2 shows predictive power of independent variables.

Table 2 Prediction of manipulation through Sociability and Self-confidence

\begin{tabular}{llllll}
\hline $\begin{array}{l}\text { Predictors of } \\
\text { Manipulation }\end{array}$ & B & $\begin{array}{l}\text { Std. } \\
\text { Error }\end{array}$ & Beta & t & $\mathrm{p}$ \\
\hline Sociability & -0.342 & 0.096 & -0.313 & -3.564 & $\mathbf{0 . 0 0 1}$ \\
Self-confidence & 0.323 & 0.089 & 0.316 & 3.606 & $\mathbf{0 . 0 0 0}$ \\
(Constant) & 1.829 & 0.329 & & 5.566 & 0.000 \\
\hline
\end{tabular}

Results analysis of research shows predictive level of sociability and self-confidence to manipulation. Examined constructs (sociability and self-confidence) explain $17.8 \%$ of prediction with $\mathrm{R}^{2}=0.178$. Sociability has significant predictive power with $\beta=-0.313$ and $p \leq 0.001$. Self-confidence features with significant predictive power $\beta=0.316$ and $\mathrm{p} \leq 0.001$ to explanation of manipulation. Hypotheses 1 verified, that sociability and self-confidence contribute in significant level to prediction of manipulation. Results analysis of research shows low predictive level of sociability and emotional stability to dependent variable, which is empathy. Table 3 shows predictive power of independent variables.

Table 3 Prediction of Empathy through Sociability and Emotional Stability

\begin{tabular}{llllll}
\hline $\begin{array}{l}\text { Predictors of } \\
\text { Empathy }\end{array}$ & $\mathrm{B}$ & $\begin{array}{l}\text { Std. } \\
\text { Error }\end{array}$ & Beta & $\mathrm{t}$ & $\mathrm{p}$ \\
\hline Sociability & 0.062 & 0.088 & 0.068 & 0.711 & 0.478 \\
Emotional stability & 0.031 & 0.091 & 0.032 & 0.336 & 0.737 \\
(Constant) & 2.076 & 0.318 & & 6.534 & 0.000 \\
\hline
\end{tabular}

Examined constructs (sociability and emotional stability) explain only $6 \%$ of prediction with $\mathrm{R}^{2}=0.006$. Sociability has not significant predictive power with $\beta=0.062$ and $p=0.478$. Emotional stability does not contribute to prediction of empathy. Regression values are not significant $(\beta=0.032$ and $\mathrm{p}=0.737$ ).

Sociability and emotional stability do not contribute in significant level to prediction of empathy. Hypotheses 2 was not verified, as we assumed that sociability and emotional stability contribute in significant level to prediction of empathy.

Results analysis of research shows predictive level of sociability and self-confidence to dependent variable, which is manipulation. Table 4 shows predictive power of independent variables.

Table 4 Prediction of Social irritability throughSociability and Self-confidence

\begin{tabular}{llllll}
\hline $\begin{array}{l}\text { Predictors of } \\
\text { Social irritability }\end{array}$ & B & $\begin{array}{l}\text { Std. } \\
\text { Error }\end{array}$ & Beta & t & $\mathrm{p}$ \\
\hline Sociability & -0.408 & 0.116 & -0.317 & -3.516 & $\mathbf{0 . 0 0 1}$ \\
Self-confidence & -0.172 & 0.108 & -0.143 & -1.582 & 0.117 \\
(Constant) & 3.107 & 0.398 & & 7.799 & 0.000 \\
\hline
\end{tabular}

Examined research constructs (sociability and selfconfidence) explain $13 \%$ of prediction with $\mathrm{R}^{2}=0.013$. Sociability has significant predictive power with $\beta=-0.408$ and $p \leq 0.001$. Self-confidence features with insignificant predictive power $\beta=-0.172$ and $p=0.117$ to explanation of social irritability. Self-confidence does not contribute in significant level to prediction of social irritability. Hypotheses 3 was not verified, as we assumed that sociability and selfconfidence contribute in significant level to prediction of social irritability. Self-confidence has not significant predictive power to prediction of social irritability. 


\section{Discussion and conclusion}

In this chapter we will interpret the influence of selected personality traits (sociability, emotional stability and self-confidence) to manipulation, empathy and social irritability.

We assumed hypothesis 1, because sociability and self-confidence contribute to prediction of empathy in significant level. We examined, that managers, who have high level of sociability and self-confidence, tend to be manipulators. The influence of sociability and self-confidence to ability of manipulation is possible through explanation of interaction between manager and employees. Previous research shows that personality with high level of sociability and self-confidence is characterize with high level of interpersonal manipulation. On the other hand people exhibiting high levels of machiavellianism (Christie and Geis, 1970) are characterized by interpersonal manipulation, such as the use of flattery and deceit, as well as by aloof, cynical, and traditionally amoral viewpoints adopted in order to promote their own goals/interests (Fehr et al., 1992; McHoskey, 1995). It seems natural to assume that Machiavellian individuals can easily read the minds of others and understand social situations which they can successfully manipulate in the service of their own intrinsic motivations (Fehr et al., 1992; Jones and Paulhus, 2009). This is the first explanation of research results, which offers an idea of Machiavellian individuals. It means, that high level of sociability and self-confidence predict Machiavellian individuals with high level of manipulation.

In addition, the apparent emotional deficit in Machiavellian individuals may be indicative of an inability to feel empathy. We know that Machiavellian individuals exhibit deficits in certain components of emotional intelligence such as emotion recognition and empathy (see Jones and Paulhus, 2009).

Research results show, that sociability and emotional stability do not contribute in significant level to prediction of empathy. Hypothesis 2 was not confirmed. Based on the research results, managers, who are sociable and emotionally stable are not empathetic. Sociability and emotional stability are personality traits, which not influence manager's empathy. From this point of view we assume that emotional stability is not automatically linked with manager's empathy. Ruby and Decety (2004) mention that empathy consists in adopting another person's point of view in order to share and understand other people's emotions or attribute emotions to them. This also implies that a distance is maintained between the two speakers in order to avoid confusion between one's own personal feelings/emotions and those experienced by the other person.

These findings imply that empathy can serve as a safeguard for ethical decision making in organizations during trying times without generally undermining organizational effectiveness. Cameron et al. (2003) referred to empathy in their treatment of positive organizational scholarship. Leadership researchers (e.g., Cameron, 2011; Choi, 2006; Day, 2001) argue increasingly for the importance of empathy for leadership effectiveness. Choi (2006), for example, asserted that empathy underlay charismatic leadership, such that empathetic leader behaviours stimulated followers' need for affiliation.

Research results show that sociability predicts social irritability and self-confidence does not predict social irritability. Sociability as personality traits of manager affects manager's social irritability. On the other hand self-confidence does not affect manager's social irritability. Social irritability is characterized through disability to adapt and annoyance by communication with other people. Managers with high level of sociability have low level of social irritability. This findings indicates Maritz's research about level of satisfaction with relation with manager by Garlick (2007). Maritz agrees that positive relation with manager is key predictor of employee's stability in company. This finding confirms effective relation and interpersonal communication between manager and employees. The results of this research show importance of personality traits, which can predict other characteristics of social intelligence (manipulation and social irritability).

In our study we show, that selected personality traits (sociability, emotional stability and self-confidence) predict manipulation and social irritability. Research findings are related to previous findings by Nakonecny, Hewstone and Stroeberg (2006), Fleškova (2007) and Kubáni (2011) about relationship between professional satisfaction and professional personality of senior executive, according state:

- for the employee who prefers frequent contact is the source of satisfaction the large consideration of his manager,

- employees who highly rate their ability to manage workload accept directive behaviour of their managers less,

- authoritative tempered employees react more strongly to directive management,

- there can be diverse functional addictions connected to job satisfaction, for example better employee workload satisfaction can lead to management satisfaction and the other way round, for the employee with a strong interaction need is the source of satisfaction manager's consideration,

- the employee with a stronger performance motivation is happier with the path-goal management and offers an employement feedback,

- happier mood and better athmosphere means higher satisfaction of the employees.

It's proven that the most important part of manager's performance is his personality, set of motives, values, emotions and interests rather than age or gender. The research identified many helpful attributes for the evaluation of employee's behaviour and his performance. Overall, this research can contribute to development of the features and skills that helps managers to manage his position. 


\section{References}

Cameron, K. (2011) Responsible leadership as virtuous leadership. Journal of Business Ethics. 98(1), pp. 25-35. DOI: 10.1007/s10551-011-1023-6

Cameron, K. S., Dutton, J. E., Quinn, R. E. (2003) Positive organizational scholarship: Foundation of a new discipline. Barrett-Koehler, San Francisco. 2003.

Cawley, M. J., Martin, J. E., Johnson, J. A. (2000) A virtues approach to personality. Personality and Individual Differences. 28(5), pp. 997-1013. DOI: 10.1016/S0191-8869(99)00207-X

Corr, P. J. (2011) Anxiety: splitting the phenomenological atom. Personality and Individual Differences. 50(7), pp. 889-897.

DOI: 10.1016/j.paid.2010.09.013

Day, D. V. (2001) Leadership development: A review in context. The Leadership Quarterly. 11(4), pp. 581-613. DOI: 10.1016/S1048-9843(00)00061-8

Dutton, J. E., Worline, M. C., Frost, P. J., Lilius, J. (2006) Explaining compassion organizing. Administrative Science Quarterly. 51(1), pp. 59-96. DOI: 10.2189 /asqu.51.1.59

Džuka, J. (2002) Psychometrické vlastnosti slovenského prekladu Bochumského inventára profesijných charakteristík osoby (BIP). (Psychometrical characteristics of slovak translation Bochum Inventory for professional personality characteristics (BIP).) Psychologie v ekonomické praxi. 42(1-2), pp. 67-76. (in Slovak)

Fehr, B., Samsom, D., Paulhus, D. L. (1992) The construct of Machiavellianism: twenty years later. In: Spielberger, C. D., Buther, J. N. (eds.) Advances in personality assessment. Vol. 9, pp. 77-116, Erlbaum, Hillsdale, NJ.

Flešková, M. (2007) Atmosféra v pracovnej skupine a pracovná spokojnost'. (Atmosphere in working group and working satisfaction.) In: Zborník z medzinárodnej vedeckej konferencie: Aktuálne trendy na trhu práce a v politike zamestnanosti. (Miscellany from international scientific conference: Current trends at labor market and employment policy.), Trenčianska univerzita Alexandra Dubčeka v Trenčíne, Trenčín, 2007, pp. 116-119. (in Slovak)

Frankovský, M., Birknerová, Z. (2012) Etický rozmer sociálnej inteligencie ako výkonovej charakteristiky. (Ethical dimension of social intelligence as a performace characteristic.) In: Psychologica XLI: zborník Filozofickej fakulty Univerzity Komenského v Bratislave. (Psychologica XLI: Miscellany of Comenius University of Faculty of Arts.), Stimul, Bratislava, 2012, pp. 163-174. (in Slovak)

Frankovský, M., Birknerová, Z. (2014). Zist'ovanie sociálnej inteligencie metodikou MESi - psychometrické charakteristiky. (Detecting Social Intelligenceby MESI Methodology - Psychometric Characteristics.) Človek a spoločnost'. 17(1), pp. 97-110. (in Slovak)

Garlick, R. (2007). Managing Your Boss: The Impact of Manager Personality and Style on Employee Performance. [Online]. Available from: http:// hospitalitynet.org/news/4032781.html. [Accessed: 8th January 2016]

Gross, J. J. (1998). Antecedent - and Response-Focused Emotion Regulation: Divergent Consequences for Experience, Expression and Physiology. Journal of Personality and Social Psychology. 74(1), pp. 224-237. DOI: $10.1037 / 0022-3514.74 .1 .224$
Gross, J. J., Thompson, R. A. (2007) Emotion Regulation: Conceptual Foundations. In: Gross, J. J. (eds.) Handbook of emotion regulation. Guilford Press, New York, 2007.

Choi, J. (2006) A motivational theory of charismatic leadership: Envisioning, empathy, and empowerment. Journal of Leadership and Organizational Studies. 13(1), pp. 24-43. DOI: 10.1177/10717919070130010501

Christie, R., Geis, F. L. (1970) Studies in Machiavellianism. Academic Press, New York, 1970.

Jones, D. N., Paulhus, D. L. (2009) Machiavellianism. In: Leary, M. R., Hoyle R. H. (eds.) Handbook of individual differences in social behavior. Guilford, New York, pp. 93-108.

Kohoutek, R. (2000) Základy psychologie osobnosti. (Basis of psychology of personality.) CERM, Brno, 2000. (in Slovak)

Kubáni, V. (2011) Psychológia práce. (Psychology of work.) Prešovská univerzita v Prešove, FHPV, Prešov. (in Slovak)

Mayer, J. D. (1998) A Systems Framework for the Field of Personality. Psychological Inquiry. 9(2), pp. 118-144. DOI: $10.1207 /$ s15327965pli0902_10

McAdams, D. P. (1996) Personality, Modernity and the Storied Self: A Contemporary Framework for Studying Persons. Psychological Inquiry. 7(4), pp. 259-321. URL: http://www.jstor.org/stable/1448813

McCrae, R. R., Costa, P. T. (1987) Validation of Five-Factor Model of Personality Across Instruments and Observers. Journal of Personality and Social Psychology. 52(1), pp. 81-90. DOI: 10.1037/0022-3514.52.1.81

McHoskey, J. W. (1995) Narcissism and Machiavellianism. Psychological Reports. 77(3), pp. 755-759. DOI: 10.2466/pr0.1995.77.3.755

Niven, K., Sprigg, C. A., Armitage, C. J. (2013) Does Emotion Regulation Protect Employees from the Negative Effects of Workplace Aggression?. European Journal of Work and Organisational Psychology. 22(1), pp. 88-106. DOI: 10.1080/1359432X.2011.626200

Pavlovich, K., Krahnke, K. (2012) Empathy, connectedness, and organisation. Journal of Business Ethics. 105(1), pp. 131-137. DOI: $10.1007 / \mathrm{s} 10551-011-0961-3$

Park, N., Peterson, C. M. (2008) Positive psychology and character strengths: Application to strengths-based school counseling. Professional School Counseling. 12(2), pp. 85-92.

Pervin, L. A., John, O. P. (1999) Handbook of personality: theory and research. Guilford Press, New York, 1999.

Ruby, P., Decety, J. (2004) How would you feel versus how do you think she would feel? In: A neuroimaging study of perspective taking with social emotions. Journal of Cognitive Neuroscience. 16(4), pp. 988-999. DOI: 10.1162/0898929041502661

Smékal, V. (2002) Pozváni do psychologie osobnosti. (Invitation to psychology of personality.) Barrister and Principal, Brno. (in Slovak) 